\title{
Dog leishmaniasis in Slovenia: a probable creation of the first enzootic focus - a case report
}

\author{
Tina Kotnik \\ Small Animal Clinic, Veterinary Faculty, University of Ljubljana, Ljubljana, Slovenia
}

KOTNIK, T.: Dog leishmaniasis in Slovenia: a probable creation of the first enzootic focus - a case report. Vet. arhiv 90, 317-322, 2020.

\section{ABSTRACT}

Leishmaniasis is a vector-borne disease caused by protozoal parasites of the genus Leishmania. Parasites are transmitted by Phlebotominae flies (Diptera, Psychodidae). Leishmania infantum is the most important species in Europe. Humans, as well as animals, can become infected. The parasite produces a visceral form of the disease that can end in death if not treated properly. Dogs are considered the main reservoir for human infection. Traditional endemic regions in Europe are the countries of the Mediterranean basin. Slovenia is considered non-endemic. The article reports a case of canine leishmaniasis $(\mathrm{CanL})$ in a Slovenian dog. This particular case was a 5 year old Brandlbracke bitch, born close to the Croatian border, but which had never crossed the Slovenian state borders. She was a regular outdoor sleeper. Beside considerable loss of weight, seborrhoeic and alopecic skin with crusts on the legs and head were noticed. Laboratory tests revealed hyperproteinaemia, hypoalbuminaemia, leucocytosis, anaemia, and thrombocytosis. An immunofluorescence antibody titre test revealed 1: $>160$ antibody titre against $L$. infantum. Clinical improvement was achieved following therapy with allopurinol. Real-time PCR performed on conjunctival swab and blood specimens 1.5 years post therapy was negative. Since Phlebotominae flies were found in the south of the country recently, and infection by other routes in this case seems unlikely, this dog was most probably infected by sand fly bites. The possibility that CanL could be spread endemically in Slovenia therefore exists.

Key words: leishmaniasis; CanL; L. infantum; sand flies; Phlebotominae

\section{Introduction}

Canine leishmaniasis (CanL) is a vectorborne disease, caused by protozoal parasites of the genus Leishmania. Parasites are transmitted by Phlebotominae flies (Diptera, Psychodidae). Historically, these insects are called sand flies because of the sandy colour of their body. Sand flies are small, mostly nocturnal insects. The adults feed on nectar and other plant-derived sugars. However, the females, in addition, feed on blood required for maturing eggs. Although many mammals, (humans, dogs, cats, horses, rabbits, foxes, jackals and rodents) may serve as hosts, dogs are considered the main reservoir of the disease (ALVAR et al., 2004). $L$. infantum is currently the predominant causative agent of visceral leishmaniasis in people and dogs in Mediterranean region. Through sand fly bites, leishmanial parasites are inoculated into the skin. They infect phagocytes and multiply in them. In the

\footnotetext{
*Corresponding author:

Tina Kotnik, PhD, Small Animal Clinic, University of Ljubljana, Veterinary Faculty, Gerbičeva 60, 1000 Ljubljana, Slovenija, Phone: + 38614779 284; Fax: + 38614779 349; E-mail: tina.kotnik@vf.uni-lj.si
} 
phagocytes, parasites are transported to the regional lymph nodes, and from there, parasites may be disseminated by infected phagocytes into different tissues all over the body. This happens in cases of inadequate immune response. Nevertheless, the majority of infected dogs $(80 \%)$ remain asymptomatic. It depends on the capability of the cellular (Th1-dominated) immune response and parasite load whether $L$. infantum infection remains asymptomatic or leads to a severe, potentially fatal disease in dogs (ALVAR et al., 1994)

Dogs with the clinically developed disease predominantly show the following symptoms: loss of body mass, intermittently elevated body temperature, lymphadenopathy, exfoliative dermatitis with onychogryphosis, epistaxis, uveitis and polyuria / polydipsia. Laboratory tests usually reveal non-regenerative anaemia, hyperproteinaemia, hypoalbuminaemia, proteinuria and uraemia (ALVAR et al., 1994).

\section{Case presentation}

In autumn 2015 a questionnaire survey was conducted using the mailing list of the Slovenian Veterinary Chamber, involving the 103 Slovenian practices dealing with small animals at that time. The survey included a few simple questions such as "have you ever been involved in the diagnostics and / or treatment of CanL case?" and "have you ever seen a CanL case in an animal born in Slovenia that has never left the country?". Amongst the answers which mainly reported infected dogs rescued from Spain and Portugal, data were found about the bitch reported in this article as the first known CanL-infected Slovenian dog that has never left the country.

This particular case was a 5 year old Austrian Black and Tan Hound bitch (Brandlbracke) named Ala. Ala was born in Kostelo (a small village close to the Croatian border). She had travelled to the Slovenian coast and to the eastern part of Slovenia, but had never crossed the state borders. When two years old she had a litter of two puppies that were killed soon after birth by another bitch living in the household. Ala was neutered a few months later. At the time of presentation, Ala was an active hunting dog. She was a regular outdoor sleeper. In autumn
2013 her owner noticed skin changes. The skin was seborrhoeic and alopecic, with crusts on the legs and head. Oedematous nodules were observed on the legs and a serous and purulent discharge was leaking from some of the nodules. Beside the skin changes she had lost $6 \mathrm{~kg}$ in quite a short period of time. In January 2014, Ala was presented to the local veterinarian. Little improvement was achieved by initial antibiotic treatment (enrofloxacine, medicated shampoos). Her basic biochemistry profile was in the normal range (urea $4.2 \mathrm{mmol} / \mathrm{L}$, creatinine $31 \mu \mathrm{mol} / \mathrm{L}$, AST $0.57 \mathrm{IU} / \mathrm{L}$, ALT $0.39 \mathrm{IU} / \mathrm{L}$, AP $1.54 \mathrm{IU} / \mathrm{L})$, but total blood proteins were found high, while blood albumins were low (Table 1).

Table 1. Total proteins, albumins and differential blood count of the bitch before treatment

\begin{tabular}{|l|c|c|c|}
\hline Measurement & Value & Unit & $\begin{array}{c}\text { Reference } \\
\text { range }\end{array}$ \\
\hline S-Proteins & $\mathbf{1 1 7}$ & $\mathbf{g} / \mathbf{L}$ & $\mathbf{6 5 - 8 0}$ \\
\hline S-Albumin & $\mathbf{1 9}$ & g/L & $\mathbf{3 2 - 5 5}$ \\
\hline Neutrophils & 67.0 & $\%$ & $40.0-75.0$ \\
\hline Limphocytes & $\mathbf{8 . 0}$ & $\mathbf{\%}$ & $\mathbf{2 0 . 0 - 5 0 . 0}$ \\
\hline Monocytes & $\mathbf{1 4 . 0}$ & $\mathbf{\%}$ & $\mathbf{2 . 0 - 1 0 . 0}$ \\
\hline Eosinophils & 5.0 & $\%$ & $1.0-6.0$ \\
\hline Basophils & & $\%$ & $0.0-2.0$ \\
\hline S-IgG & $\mathbf{2 . 1 3}$ & g/L & $\mathbf{6 . 3 6 - 1 7 . 0 1}$ \\
\hline S-IgA & $<0.24$ & g/L & $0.80-4.36$ \\
\hline S-IgM & 0.81 & g/L & $0.36-1.42$ \\
\hline
\end{tabular}

Complete blood count showed leucocytosis, anaemia, and thrombocytosis (Table 2). Differential blood count showed lymphopenia with monocytosis and low IgG numbers (Table 1). An immunofluorescence antibody titre test (IFAT; BioMerieux, with a cut-off dilution 1:64) revealed end dilution of $1:>160$ antibody titre against $L$. infantum.

Clinical improvement was achieved following therapy with allopurinol in a daily dose of $20 \mathrm{mg} /$ $\mathrm{kg}$. Ala gained her weight back, and after clinical improvement treatment by the local veterinarian was ended. At the time of the photographs enclosed (winter 2016) the bitch had been off the allopurinol treatment for 1.5 years, without any reappearance of symptoms of systemic disease (Fig. 1-3). 
T. Kotnik: Dog leishmaniasis in Slovenia: a probable creation of the first enzootic focus

Table 2. Complete blood count of the bitch before treatment

\begin{tabular}{|l|c|c|c|}
\hline Measurement & Value & Unit & $\begin{array}{c}\text { Reference } \\
\text { range }\end{array}$ \\
\hline Leucocytes & $\mathbf{1 2 . 6}$ & $\mathbf{1 0}^{9} / \mathbf{L}$ & $\mathbf{4 . 0 - 1 0 . 0}$ \\
\hline Erithrocytes & 4.31 & $10^{12} / \mathrm{L}$ & $4.2-6.3$ \\
\hline Hemoglobin & 112 & $\mathrm{~g} / \mathrm{L}$ & $120-180$ \\
\hline Hematocrit & $\mathbf{0 . 3 2 1}$ & $\mathbf{1}$ & $\mathbf{0 . 3 7 - 0 . 5 4}$ \\
\hline MCV & $\mathbf{7 4}$ & $\mathbf{f L}$ & $\mathbf{8 1 - 9 4}$ \\
\hline MCH & $\mathbf{2 5 . 9}$ & $\mathbf{p g}$ & $\mathbf{2 6 - 3 2}$ \\
\hline MCHC & 348 & $\mathrm{~g} / \mathrm{L}$ & $310-350$ \\
\hline RDW & $\mathbf{1 0 . 7}$ & $\mathbf{\%}$ & $\mathbf{1 1 . 6 - 1 3 . 7}$ \\
\hline Thrombocytes & $\mathbf{3 6 3}$ & $\mathbf{1 0} / \mathbf{L}$ & $\mathbf{1 4 0 - 3 4 0}$ \\
\hline MPV & 7.9 & $\mathrm{fL}$ & $7.4-10.4$ \\
\hline
\end{tabular}

Altered values are written in bold

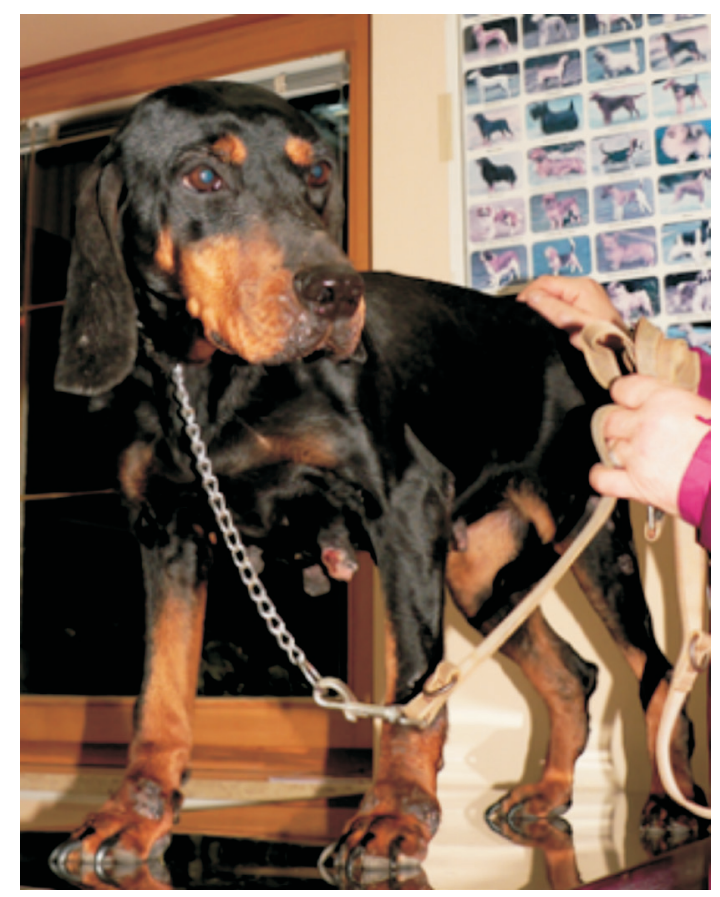

Fig. 1. The bitch in the winter of 2016, a year and a half after cessation of treatment

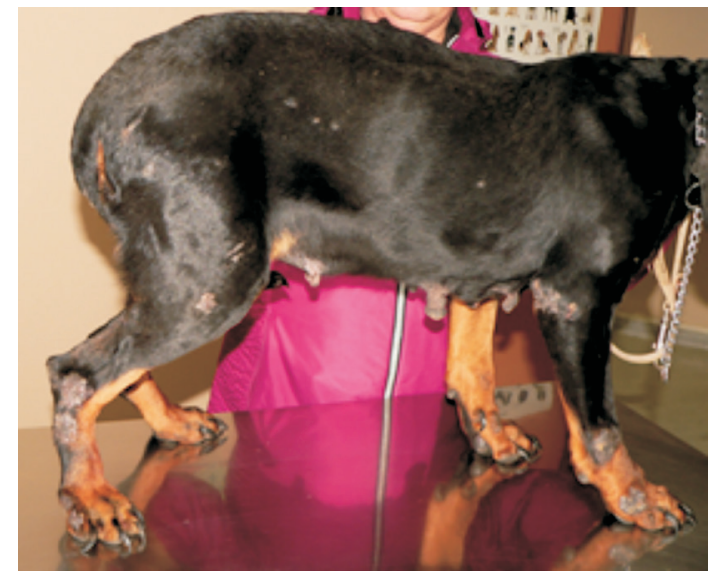

Fig. 2. The bitch in the winter of 2016, a year and a half after cessation of treatment

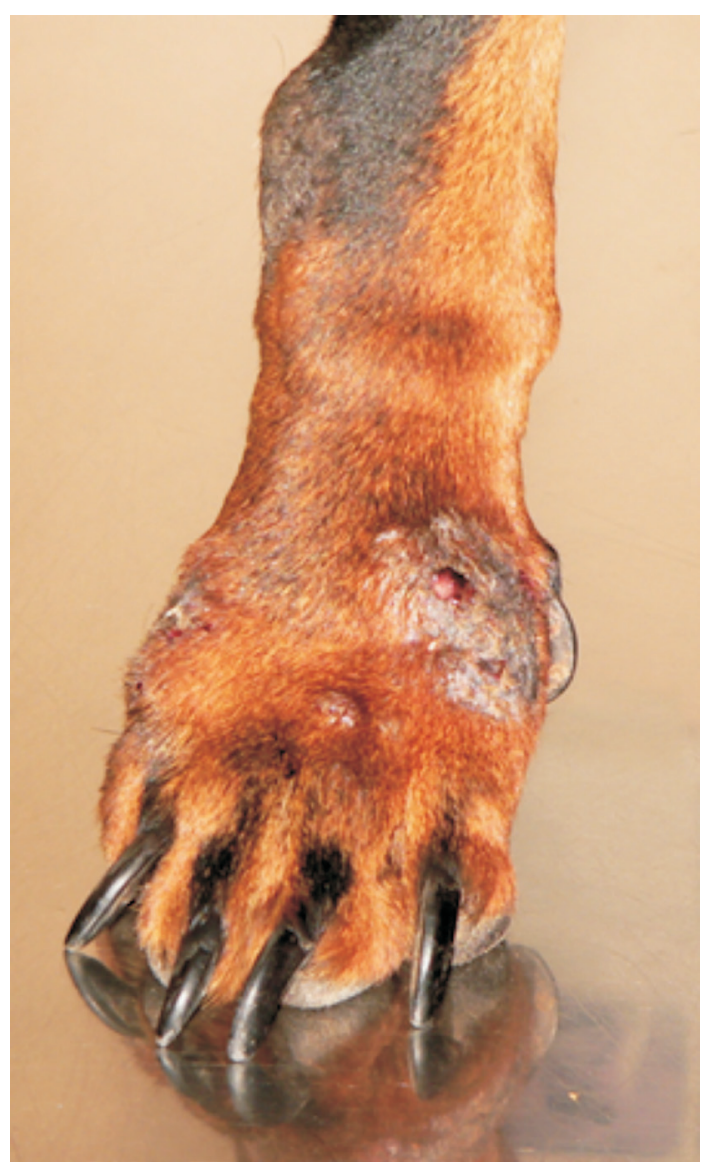

Fig. 3. A close-up of the skin photographed in the winter of 2016, a year and a half after cessation of treatment 
However, the owner had been observing seasonal seborrhoeic skin changes every winter with regular spring ameliorations. Skin changes are also visible on the photographs. Cytology examination of swab smears from the lesions revealed no Leishmania parasites, but showed degenerate neutrophils with phagocytosis of cocci. Real-time PCR, performed on conjunctival swab and blood specimens at this point was negative. Antibiotic treatment was suggested to treat the pyoderma. Unfortunately, no laboratory follow-up was done.

\section{Discussion}

The majority of Leishmania-infected dogs never show the disease clinically. The incidence rate in endemic regions is usually less than $10 \%$, while seroprevalence can be as high as $90 \%$ (SOLANOGALLEGO et al., 2011). In endemic regions, about $20 \%$ of infected dogs never show symptoms but eliminate parasites before they could be disseminated from the lymph nodes all over the body. Another $40 \%$ of infected dogs do not show symptoms either but they are still carriers and therefore infectious to sand flies. Only $40 \%$ of infected dogs develop the disease clinically (FERRER et al., 1995). Recent studies show that two of the major risk factors for CanL are an age of 2 years or more, and sleeping mostly outdoors (CORTES et al., 2012). Those were also risk factors in our case.

Infected dogs may show skin changes that can be present in about $60 \%$ of symptomatic dogs (FERRER et al., 1995). Dogs become anorexic by antigen-antibody complex overload - producing chronic kidney disease. Kidney failure is the main cause of death in CanL (BOURDEAU et al., 2014). Dogs that have developed a visceral form of disease look tired, weak, and depressed. These are the consequences of anaemia, muscle atrophy, and poliarthropathy. Lymphadenopathy is also very common. Lymphadenopathy can be localized but in the majority of cases it is generalised. Blood loss (often in the form of epistaxis) is also common and it is the second most common cause of death in dogs (PETANIDES et al., 2008). Skin inflammation, depression, and weight loss were also present in our case. Anaemia, hyperproteinaemia, and hypoalbuminaemia were noticed in laboratory parameter deviations. The laboratory test results described in our case are common in CanL (BOURDEAU et al., 2014).

Before treatment, PCR was not performed in our dog. Treatment was established on the basis of the clinical picture and positive IFAT test. Two years after the clinical course of disease, real time PCR for Leishmania spp. was performed. It revealed negative results. Real time PCR is the best test to be performed during the follow-up period. The negative results in our case could be a consequence of parasite elimination by the immune system or a lack of test sensitivity. PCR sensitivity varies considerably according to the type and number of different samples evaluated, the target DNA copy numbers, and the target DNA sequence (PALTRINIERI et al., 2016; SOLANO-GALLEGO et al., 2017). In our case, blood and conjunctival swabs were sampled. According to the literature, bone marrow, lymph node, spleen, and skin allow the most sensitive detection of Leishmania DNA, with PCR of bone marrow currently considered as the gold standard for diagnosis of CanL. Whole blood PCR is less sensitive (SOLANO-GALLEGO et al., 2017). In our case, whole blood and conjunctival swabs were used for PCR. The major problem in obtaining bone marrow for PCR is the invasiveness of the procedure and its considerable cost. Nevertheless, PCR sensitivity using noninvasively obtained conjunctival swabs can be $78.4 \%$, when testing dogs in a non-endemic area (GEISWEID et al., 2013).

The photographs of the bitch presented in this article were taken in winter 2016. According to the owner's description, Ala had been showing seasonal deteriorations of skin condition every winter, with following ameliorations every spring. These features could most probably be ascribed to an allergic disease. When symptoms of the disease appear and spontaneously disappear without any treatment, they are usually provoked by seasonal allergens. Allergens that atopic dogs are most commonly sensitized to in our experience are food storage mites and house dust mites, followed by grass pollens. Pyoderma, also proved in Ala, is a common feature in allergic disease (KOTNIK, 2007). Unfortunately, no allergic tests were performed in our case, so any further discussion on these symptoms remains speculation. 
Various infection routes have been proved in dogs (the placental route, by mating, by blood transfusion, and by infected fly bites) (SOLANOGALLEGO et al., 2011). Other routes of infection than via fly bites seem unlikely in our CanL case. Vertical transmission seems unlikely, since Ala's mother was born in Slovenia and never travelled out of the country. According to the owner, she was never seriously ill nor was her mating male, Ala's father. Both dogs were generally healthy, the mother died when old and father was euthanized after a serious hunting injury. Horizontal transmission from Ala's mate seems unlikely since the male was of Slovenian origin, never travelled out of the country and was healthy at the time of mating (data obtained by phone interview). Ala had never left the country, regularly slept outdoors and never had a blood transfusion. Therefore it is very likely that Ala was infected by a Phlebotomine fly bite.

The region where Ala was living has a mild microclimate and is close to the Croatian border. In this region, the presence of important leishmania Phlebotomine fly vectors were recently proved (IVOVIĆ et al., 2015). Amongst the five collected species that were found in the region, two of them - P. neglectus and P. perniciosus - are well known and proven vectors of $L$. infantum in the Mediterranean region (DEPAQUIT et al., $2010)$. Due to their limited flight range $(<1 \mathrm{~km})$, transmission of leishmaniosis within endemic areas is often intermittent, with characteristically small and separate foci close to the reservoir host habitats (JACOBSON et al., 2003). Sand flies seeking blood meals generally advance upwind in short flights, close to the ground, guided by host-derived cues, such as $\mathrm{CO}_{2}$, temperature, and humidity gradients (KILLICK-KENDRICK, 1999). Due to rapid climatic changes, $P$. neglectus has shown rapid aerial expansion from the traditional endemic regions of the Balkans, and was recently found as far north as near Budapest (Hungary) (FARKAS et al., 2011). Spread of sand flies to Slovenia (IVOVIĆ et al., 2015) most probably occurred from the well-known endemic region of Dalmatia (Croatia), where human leishmaniosis cases were diagnosed as early as in 1930, and the L. infantum seroprevalence ratio in dogs was found to be as high as $42.85 \%$ (ŽIVIČNJAK et al., 2005). Recent data on seropositivity of the human population resident in Istria near the southern Slovenian border (ŠIŠKKO-KRALJEVIĆ et al., 2013), together with import of infected dogs from endemic countries (KOTNIK and IVOVIĆ, 2017), and the confirmed presence of sand flies in the region (IVOVIĆ et al., 2015) represent a threat for the creation of the first enzootic focus in Slovenia. A large seroprevalence study was therefore recently started in Slovenia, supported by financial sources from the World Health Organisation.

\section{References}

ALVAR, J., R. MOLINA, M. SAN ANDRES, M. TESOURO, J. NIETO, M. VITUTIA, F. GONZALEZ, M. D. SAN ANDRES, J. BOGGIO, F. RODRIGUEZ (1994): Canine leishmaniasis: clinical, parasitological and entomological follow-up after chemotherapy. Annal. Tropic. Medic. Parasitol. 88, 371-378.

ALVAR, J., C. CANAVATE, R. MOLINA, J. MORENO, J. NIETO (2004): Canine leishmaniasis. Adv. Parasitol. 57, $1-88$.

BOURDEAU, P., M. N. SARIDOMICHELAKIS, A. OLIVEIRA, G. OLIVA, T. KOTNIK, R. GALVEZ, V. FOGLIA MANZILLO, A. F. KOUTINAS, I. PEREIRA DA FONSECA, G. MIRO (2014): Management of canine leishmaniosis in endemic SW European regions: a questionnaire-based multinational survey. Parasit. Vectors. 7,110 .

CORTES, S., Y. VAZ, R. NEVES, C. MAIA, L. CARDOSO, L. CAMPINO (2012): Risk factors for canine leishmaniasis in an endemic Mediterranean Region. Vet. Parasitol. 189, 189-196.

DEPAQUIT, J., M. GRANDADAM, F. FOUQUE, P. E. ANDRY, C. PEYREFITTE (2010): Arthropod-borne viruses transmitted by Phlebotomine sandflies in Europe: a review. Euro Surveill. 15, 19507.

FARKAS, R., B. TANCZOS, G. BONGIORNO, M. MAROLI, J. DEREURE, P. D. READY (2011): First surveys to investigate the presence of canine leishmaniasis and its phlebotomine vectors in Hungary. In: Vector-borne and Zoonotic Diseases. (Liebert M. A., Ed.), Inc.

DOI: $10.1089 /$ vbz.2010.0186

FERRER, L., M. J. AISA, X. ROURA, M. PORTUS (1995): Serological diagnosis and treatment of canine leishmaniasis. Vet. Rec. 136, 514-516.

GEISWEID, K., K. WEBER, C. SAUTER-LOUIS, K. HARTMANN (2013): Evaluation of a conjunctival swab polymerase chain reaction for the detection of Leishmania infantum in dogs in a non-endemic area. Vet. J. 198, 187-192. DOI: $10.1016 /$ j.tvj1.2013.07.025 
T. Kotnik: Dog leishmaniasis in Slovenia: a probable creation of the first enzootic focus

IVOVIĆ, V., K. KALAN, S. ZUPAN, E. BUŽAN (2015): Illegal waste sites as a potential micro foci of mediterranean leishmaniasis: first records of phlebotomine sand flies (Diptera: Psychodidae) from Slovenia. Acta Vet. (Beogr.) $65,348-357$.

JACOBSON, R. L., C. L. EISENBERGER, M. SVOBODOVA, G. BANETH, J. SZTERN, J. CARVALHO, A. NASEREDDIN, M. EL FARI, U. SHALOM, P. VOLF, J. VOTYPKA, J. P. DEDET, F. PRATLONG, G. SCHONIAN, L. F. SCHNUR, C. L. JAFFE, A. WARBURG (2003): Outbreak of cutaneous leishmaniasis in northern Israel. J. Infect. Dis. 188, 1065-1073.

KILLICK-KENDRICK, R. (1999): The biology and control of phlebotomine sand flies. Clin. Dermatol. 17, 279-289.

KOTNIK, T. (2007): Retrospective study of presumably allergic dogs examined during one year period at Veterinary faculty of Ljubljana, Slovenia. Vet. arhiv 77, 453-462.

KOTNIK, T., V. IVOVIĆ (2017): Living on the edge: border countries should have strict veterinary and health policy on leishmaniasis, the epidemiology and ecology of leishmaniasis. In: The Epidemiology and Ecology of Leishmaniasis. (Claborn, D., Ed.), InTech. Cop., Rijeka, pp. 3-16.

PALTRINIERI, S., L. GRADONI, X. ROURA, A. ZATELLI, E. ZINI (2016): Laboratory tests for diagnosing and monitoring canine leishmaniasis. Vet. Clin. Pathol. 45, 552-578.

DOI: $10.1111 /$ vcp. 12413
PETANIDES, T. A., A. F. KOUTINAS, M. E. MYLONAKIS, J. DAY, M.N. SARIDOMICHELAKIS, L. S. LEONTIDES, R. MISCHKE, P. DINIZ, E. B. BREITSCHWERDT, M. KRITSEPI, V. A. GARIPIDOU, C. K. KOUTINAS, S. LEKKAS (2008): Factors associated with the occurrence of epistaxis in natural canine leishmaniasis (Leishmania infantum). J. Vet. Intern. Med. 22, 866-872.

SOLANO-GALLEGO, L., G. MIRO, A. KOUTINAS, L. CARDOSO, M. G. PENNISI, L. FERRER, P. BOURDEAU, G. OLIVA, G. BANETH (2011): LeishVet guidelines for the practical management of canine leishmaniosis. Parasit. Vectors 4, 86 .

SOLANO-GALLEGO, L., L. CARDOSO, M. G. PENNISI, C. PETERSEN, P. BOURDEAU, G. OLIVA, G. MIRO, L. FERRER, G. BANETH (2017): Diagnostic challenges in the era of canine Leishmania infantum vaccines. Trends Parasitol. 33, 706-717.

ŠIŠKO-KRALJEVIĆ, K., A. JERONČIĆ, B. MOHAR, V. PUNDA-POLIĆ (2013): Surveillance and outbreak reports Asymptomaic Lishmania infantum infections in humans living in endemic and non-endemic areas of Croatia, 20072009. In: Eurosurveillance Special edition: Leishmaniasis in Europe. (Steffens I., K. Hagmaier, K. Wilson, W. Wilson, Eds.), ECDC, Stockholm, pp. 24-31.

ŽIVIČNJAK, T., F. MARTINKOVIĆ, A. MARINCULIĆ, V. MRLJAK, N.KUČER, V.MATIJATKO,Z.MIHALJEVIĆ, R. BARIĆ-RAFAJ (2005): A seroepidemiologic survey of canine visceral leishmaniasis among apparently healthy dog in Croatia. Vet. Parasitol. 131, 35-43. DOI: $10.1016 /$ j. vetpar.2005.04.036

Received: 29 May 2018

Accepted: 10 June 2019

KOTNIK, T.: Lišmanioza psa u Sloveniji: vjerojatno stvaranje prvog enzootskog žarišta - prikaz slučaja. Vet. arhiv 90, 317-322, 2020.

\section{SAŽETAK}

Lišmanioza je bolest koja se prenosi vektorima, a uzrokuje ju protozoalni parazit iz roda Leishmania. Parazite prenose muhe Phlebotominae (Diptera, Psychodidae). Leishmania infantum najvažnija je vrsta u Europi, kojom se mogu invadirati i ljudi i životinje. Parazit uzrokuje visceralni oblik bolesti koji može završiti smrću ako se odgovarajuće ne liječi. Psi se smatraju glavnim rezervoarom za invaziju u ljudi. Tradicionalne endemijske regije u Europi jesu zemlje koje se nalaze u Mediteranskom bazenu. Slovenija se ne smatra endemijskim područjem. Članak peikazuje slučaj lišmanioze psa (CanL) iz Slovenije. Radi se o pet godina staroj kuji pasmine austrijski ravnodlaki gonič (Brandlbracke) okoćenoj u Sloveniji blizu hrvatske granice, i koja nikad nije napuštala Sloveniju. Kuja je redovito boravila vani. Osim znatnoga gubitka tjelesne mase, uočena je seboroična i alopecična koža s krastama na ekstremitetima i glavi. Laboratorijski testovi pokazali su hiperproteinemiju, hipoalbuminemiju, leukocitozu, anemiju i trombocitozu. Titar protutijela Imunofluorescencijom utvrđen je titar protutijela u vrijednosti $1:>160$ za L. infantum. Liječenje alopurinolom dovelo je do kliničkog poboljšanja. Lančana reakcija polimerazom u stvarnom vremenu učinjena iz obriska konjunktiva i uzorka krvi 1,5 godina poslije liječenja bila je negativna. Iako je u novije vrijeme dokazano da insekata iz skupine Phlebotominae ima na jugu zemlje i invazija drugim putem ne čini se vjerojatnom, kuja je najvjerojatnije invadirana ubodom pješčane mušice, stoga postoji mogućnost endemijskog širenja lišmanioze psa u Sloveniji.

Ključne riječi: lišmanioza; CanL; L. infantum; pješčana mušica; Phlebotominae 